\title{
A remarkable remnant mesic deciduous forest stand: are composition and structure of old-growth retained?
}

\author{
P. F. Maycock ${ }^{1}$ and D. Fahselt ${ }^{2}$ \\ ${ }^{1}$ Department of Botany, Erindale College, University of Toronto, Mississauga, Ontario, L5M 1C6, Canada. \\ Fax: 416-828-3792 \\ ${ }^{2}$ Department of Plant Sciences, University of Western Ontario, London, Ontario, N6A 1W6, Canada. \\ Fax: 519-661-3935, e-mail: dfahselt@julian.uwo.ca
}

Keywords: Detrended Correspondence Analysis, Maple-beech forest, Old-growth, Ordination, Species composition, Stand size, Southern Ontario, Vegetation.

\begin{abstract}
Old-growth forests are declining throughout eastern North America, especially toward the northern limit of the deciduous formation where gently undulating topography and milder climate especially encourage human activity. Remnants exist, but do they retain the defining characteristics of the original vegetation? The objective was to marshal information required to answer this question, and toward this objective we assessed vegetation in a small 1 ha remnant of maple-beech forest with no history of past logging and compared it to well known and larger old-growth areas in the region. We used Curtis's (1959) Point Quarter method to provide full quantitative data for trees, saplings, shrub and herbs. Size class distribution of trees and successional status of the stand were assessed. As a general conclusion, we found that tree species richness of our remnant was higher than most recognized large old-growth forests and, while the herbaceous understorey was poorer in species than larger tracts, it exhibited three provincially rare species. Furthermore, the successional status and structural complexity of the remnant were typical of old-growth forests. In overall comparative terms, the remnant was found not be an outlier when ordinated with larger forests. It thus is safe to conclude that this remnant constitutes an ecological benchmark well worth protection, despite its limited size.
\end{abstract}

Abbreviations: asl - above sea level; BABH - basal area $1 \mathrm{~m}$ above ground; DBH - diameter $1 \mathrm{~m}$ above ground; DCA - detrended correspondence analysis; DF - density-frequency index or sum of relative frequency and relative density; DFD - sum of relative density; relative frequency and relative dominance also called importance value; UWO - University of Western Ontario.

Nomenclature: Fernald (1950)

\section{Introduction}

Virgin stands are essentially non-existent (Hunter and White 1997) and old-growth systems are uncommon, so interest in old-growth forest systems as ecological benchmarks has strongly increased in recent times (Runkle 1996, Martin 1992, Leverett 1996). The eastern deciduous forests of North America attain their northern limits in extreme Southern Ontario at about $43^{\circ} 30^{\prime} \mathrm{N}$ where they are surprisingly rich and include 100 species of woody plants that can grow to tree size (Maycock 1963). However, the region now supports only widely separated islands of forest, most of them highly modified, and each usually comprises less than ten hectares. The largest and most notable examples of old-growth in the region include Springwater Forest in Elgin County and Backus Forest in Norfolk County, although both of these were at one time subject to selective logging.
Old-growth has been defined by many authors (e.g., Oliver and Larson 1990), but criteria vary from one paper to another, due to inherent differences between forest types and to the different perspectives of biologists and foresters (Leverett 1991). The continuum existing in time and space between second-growth and old-growth forests (Hunter and White 1997) also makes definition of oldgrowth somewhat arbitrary. The most extensive list of old-growth criteria was probably that assembled by Martin (1992), while Pfister (1987) is an author who relied on relatively few distinguishing characteristics. Structural aspects characterizing old-growth forests in the Eastern United States in both the Deciduous and Deciduous-Evergreen forests were summarized by Leverett (1996) and Runkle (1996). Features commonly considered typical of old-growth are age and size of trees and snags, canopies with multiple layers, presence of fallen logs, plus intact 
soils and understorey. Autogenicity and lack of human intervention are other widely-used criteria (Runkle 1996). Areal extent, on the other hand, is not explicitly mentioned as a diagnostic feature of old-growth by most authors (Habeck 1988, Juday 1988, Spies and Franklin 1988, Parker 1989, Oliver and Larson 1990, Brisson et al. 1992, Martin 1992, Peterken 1992, Wells et al. 1998), but Leopold et al. (1988) used 8 ha as minimal size in his definition. It would in fact be understandable if a minimum size were necessary to preserve old-growth features, due to the possibility of edge effects.

A large number of publications, both scientific and general, deal directly with old-growth or are included in lists of literature (Nowacki and Tiranonsky 1993, Tyrrell et al. 1998) simply because they mention old-growth briefly. Some of the papers are substantial botanically while many deal primarily with other aspects, such as fauna, hydrology and soils or the theoretical concept of old-growth. Botanical contributions include those that are physiologically-oriented or floristic, as well as vegetational and quantitative. Vegetational or community studies often involve the tree layer only, or just the understorey. Often they include only partial species listings, and some deal mainly with disturbance phenomena. Some, even though quantitative, present information from one stand per vegetational type, or provide density and basal area of trees without frequency values or importance values for species. Few contributions concern the northernmost extension of the deciduous forest in North America.

Because little comprehensive quantitative information has been published on old-growth communities, particularly in Ontario, we wrote this paper to fully document vascular vegetation in an urban remnant of maple-beech forest, a vegetational community that was once distributed widely throughout the region. This small local example is of particular importance because it has apparently never been subject to selective logging. A further objective was to make quantitative comparisons within the same region with similar but more extensive forests considered to be old-growth.

\section{Location and description of the area}

The maple-beech forest fragment of approximately 1 ha, was located on the campus of UWO in the city of London, Ontario $\left(81^{\circ} 16^{\prime} \mathrm{W}, 43^{\circ} 1^{\prime} \mathrm{N}\right)$, within the Southern Deciduous Forest Region in southern Ontario (Maycock 1963). It is separated from an even smaller fragment of similar composition by a thoroughfare $15 \mathrm{~m}$ wide. The UWO forest at $255 \mathrm{~m}$ asl is west and $600 \mathrm{~m}$ downstream from the junction of the Medway River with the north branch of the Thames River where its channels breach the Arva Moraine laid down during the Wisconsin glaciation (Dreimanis et al. 1998).

The postglacial history of this site has been reconstructed by geomorphologists, and changes in the course of the Thames in this area have been determined and mapped (Dreimanis et al. 1998). The slope on which the forest occurs is probably the riverbank associated with the first channel running from glacial Lake London at least 10,000 years ago. The site involves three knolls facing south with $5^{\circ}$ slopes separated by two draws that represent the courses of tributaries once leading into the old river channel. Extensive bands of alluvium which must have been laid down at various stages of river development are present along these early channels, although deposits relating to the earliest stage seem to have been at least partly removed by erosion, as they are not found in the soil profile. However, toward the upper reaches of the slope rounded water-worn cobble stones attest to the riverine origins of the site.

The existing soils are clay well-compacted below 20 $\mathrm{cm}$. A litter layer is $2.5 \mathrm{~cm}$ deep with a layer of ferment $0.7 \mathrm{~cm}$ immediately beneath it and a trace of humus below that at the interface with the $\mathrm{A}_{1}$ horizon. The $\mathrm{A}_{1}$ is $18 \mathrm{~cm}$ deep composed of dark brown clay, and a $12.5 \mathrm{~cm}$ thick layer of yellow brown compacted clay beneath this could be considered a $\mathrm{B}_{1}$ layer. Then, another $10 \mathrm{~cm}$ below this the $\mathrm{B}_{2}$ is composed of highly compacted red clay which forms the bulk of the B layer. The penetration of water is impeded by these strongly compacted layers.

At the top of a rise on the north edge of the forest is a substantial building, the School of Business, while the south and west sides are bounded by sodded verges and roads and the east by lawns. The larger draw through the forest was in the recent past used as a footpath and a sewer line was constructed in this corridor in 1961 although the forest canopy was not broken in the process. This somewhat disturbed draw has nevertheless not been invaded by alien species, but neither has it yet been fully repopulated with native saplings or tree seedlings.

\section{Methods}

Sampling took place in early July 1991. The forest was reconnoitred to ensure homogeneity and a presence list of all trees and shrubs and understorey herbs was compiled within it. We used the Point Quarter Method of vegetational analysis as the efficacy of this method was long ago established by Curtis (1959) in Wisconsin, USA. It yields repeatable density and dominance values much more efficiently than tree-by-tree whole plot inventories, 
and also demonstrates within-stand distribution in the form of frequencies for each vascular species in the community.

Avoiding old walking paths, we laid out lines from east to west at least $10 \mathrm{~m}$ from the forest edge, and points were placed at intervals of approximately $10 \mathrm{~m}$ along each. At each point intersects were used to divide the forest into four quadrants or quarters. In each quadrant we identified the nearest tree $\left(77 \mathrm{~cm}^{2} \mathrm{BABH}\right)$ and recorded its distance from the point, as well as its $\mathrm{BABH}$. The nearest sapling $(2.5 \mathrm{~cm} \mathrm{DBH})$ in each quadrat was also identified and its distance from the point measured. Using 20 points, this produced a random sample of 80 trees and 80 saplings. Cover provided by the overhead canopy was estimated above each point and, to sample the understorey, $1 \mathrm{x} 1 \mathrm{~m}$ quadrats were laid at alternate points. Percentage cover of individual species and total cover of the shrub and herb layers were estimated in each quadrat. Frequency was calculated for each species as per cent occurence in quadrats, and a frequency value of 1 was arbitrarily assigned to shrubs and herbs recorded as present in the stand but not falling into any quadrat. In the field we collected specimens of plants that were difficult to identify and these were determined subsequently. Finally, we described structural features of the stand and recognizable vegetational layers along with dominant plant species in each. In addition we estimated site moisture status, and recorded microclimate, soil $\mathrm{pH}$ and texture. Because spring ephemerals were not present at the time of first sampling, we recorded these separately in ten $1 \mathrm{mx} 1 \mathrm{~m}$ quadrats in the spring of 1999 using the same methods as for summer understorey sampling .

We determined importance values, or DFD's, for each tree species as the sum of relative frequency, relative density and relative dominance. The three components totalled 300 for the stand and, for the purpose of calculations, tree species present in the stand but not appearing in the sampling data were arbitrarily assigned an importance value of 1 . Density-frequency indices (DF's) were calculated for sapling species. For understorey species, frequency was calculated for each herb and shrub understorey species as per cent occurrence in quadrats, and we arbitrarily assigned a value of 1 to those recorded as present in the stand, but not falling into any quadrat. Mean estimated cover percentages for herbs, shrubs, tree seedlings and total vegetation were determined, as were overpoint canopy coverages. After positive identification of unknowns, presence lists were adjusted to include these.

We expressed size structure in the forest on the basis of size class distribution of trees as defined by Curtis (1959) in the Deciduous Forests of Wisconsin. Following his approach, stems were categorized into four classes: stems $77-516 \mathrm{~cm}^{2}$ BABH as the smallest size class, I, with 2064 and $8256 \mathrm{~cm}^{2}$ (multiples of 4) as upper limits of II and III, the next larger classes. The fourth and largest class, IV, included stems $8256 \mathrm{~cm}^{2}$.

To determine the relationship of the UWO forest to larger forests of its type, we undertook Detrended Correspondence Analysis (Hill and Gauch 1980) using the CANOCO program, Version 4.0 written by Cajo J.F. Ter Braak Centre for Biometry, Wageninen, The Netherlands. This was done for both stands and tree species based on quantitative tree data from the UWO stand and eleven old-growth stands in the Southern Deciduous Forest region of Ontario drawn from the files of the Plant Ecology Laboratory, University of Toronto, Mississauga, Ontario. Importance values of tree species were plotted individually on the stand ordination in an attempt to ascertain patterns of relationships to environmental, compositional or other ecological gradients.

We attempted to determine the ages of selected trees of greatest girth, but all of the specimens sampled with an increment borer in the UWO forest proved to have hollow centers and it was thus impossible to read the inner series of rings from the cores. Age determinations were therefore made on specimens of the same species in old-growth stands at Springwater forest $30 \mathrm{~km}$ SE of London, where the entire tree ring profile could be accessed. It was assumed that a similar size to age relationship prevailed at UWO.

\section{Results}

Flora

A total of 55 species of vascular plants was recorded. Except for four introductions from Europe: Prunus avium, Alliaria officinalis, Rhamnus cathartica and Epipactis helleborine, all species were native. The latter alien acts almost as a native, interacting in a non-aggressive fashion in seemingly undisturbed natural situations. Eighteen species were found as trees within the forest and only two, Celtis occidentalis and Juglans nigra were Carolinian in distribution. The others were common widespread trees of the Eastern Deciduous Forests. Three species of maple, two of elm, two of oak and two walnuts were included. All were found in the upper canopy except Carpinus caroliniana and Ostrya virginiana, both of which are typically small trees.

Understorey plants included 10 shrubs, 26 herbs and one woody liana. The most common family was Liliaceae with six species, followed by Cyperaceae with five, Rosaceae and Compositae with three and Celastraceae, 
Caprifoliaceae and Cruciferae with two members each. Other families were each represented by a single species. The most common genus was Carex with five species, while Euonymus, Trillium, Viburnum, Solidago, and Erythronium were represented by two species each. In terms of life forms, there were 16 trees, six tall, three medium and one low shrub, 20 medium herbs and six low herbs, as well as a single woody liana. Three uncommon species were the provincially rare Carex jamesii, C. hirtifolia (Ball and White 1982) and Euonymus atropurpureus (Keddy 1984).

\section{Forest structure}

Structurally the forest was quite complex with a threetiered tree canopy. The high upper canopy attained a height of $26 \mathrm{~m}$ and formed a continuous deep leafy cover, with mean canopy cover $97 \%$. Acer saccharum was the main dominant in this layer but other species were scattered throughout: Fagus grandifolia, Acer nigrum, Prunus serotina, Ostrya virginiana, Juglans nigra and Carya cordiformis. A second more or less continuous lower tree canopy existed at approximately the $20 \mathrm{~m}$ level. In it, Acer saccharum and A. nigrum were the major contributors and Prunus serotina, Ostrya virginiana, Tilia americana, Ulmus rubra and U. americana were minor constituents. A third continuous layer was present at 6-9 $\mathrm{m}$ and was in reality a reproduction layer composed of saplings of younger woody members which may eventually succeed in growing into the upper layers and replacing larger older specimens which may be lost. This layer, strongly dominated by Acer saccharum and A. nigrum, provided a basis for predicting future stand development. Saplings of other species with only a minor structural influence in this layer were Carpinus caroliniana and Fagus grandifolia.

The understorey contributed relatively little to structure or total biomass. Medium-tall shrubs comprised a decidedly discontinuous layer at $1 \mathrm{~m}$ and Prunus virginiana was the only significant contributor. A discontinuous low shrub layer $(10 \mathrm{~cm})$ had a single species, Euonymus obovatus. A medium herb layer $(40 \mathrm{~cm})$ was intermittent and dominated by Smilacina racemosa, Podophyllum peltatum and Hydrophyllum virginianum, each with the tendency to occur in large clones. Arisaema atrorubens also contributed to this layer as did Alliaria officinalis, the latter an aggressive introduction which has invaded many of our native forests. However, it exhibited minimal cover in the UWO site. Few vines of the one liana, Vitis riparia, climbed to higher levels, and there was essentially no cryptogamic layer of mosses or lichens. The early spring understorey layer was composed of Erythronium ameri- canum and E. albidum, with an admixture of Dentaria laciniata.

The structural aspects referred to above reflect layering or stratification, but spacial organization was also manifest in terms of placement throughout the forest area. The average spacing between trees was $3.6 \mathrm{~m}$, reflecting a density of 773 trees ha ${ }^{-1}$. Tree trunks ranging from 77 $\mathrm{cm}^{2}$ to $5806 \mathrm{~cm}^{2} \mathrm{BABH}$ were irregularly spaced throughout the forest, with the mean size of those sampled 661 $\mathrm{cm}^{2}$. Total dominance, or basal area $\mathrm{ha}^{-1}$, was approximately $511,000 \mathrm{~cm}^{2}$. Tree density and total dominance $\mathrm{ha}^{-1}$ were well within the ranges for regional old-growth forests of a similar type.

The contribution of saplings must be included in a discussion of structure because, while they are much smaller than trees, there can be many more per unit area in almost all forest systems. The average distance between saplings was $2.7 \mathrm{~m}$ and density was $1372 \mathrm{ha}^{-1}$. This was relatively high, reflecting a pronounced reproduction layer that added to the complexity of horizontal as well as vertical structure in the forest. As well as being numerous, saplings contributed significantly to the total basal area of stem wood. Taking the mean BABH of saplings as $20 \mathrm{~cm}^{2}$ an additional $27,440 \mathrm{~cm}^{2}$ of basal area was contributed, and combined with the basal area of trees, produced an estimate of standing wood biomass of $538,440 \mathrm{~cm}^{2} \mathrm{ha}^{-1}$, which is comparatively high for mesic stands in the region.

Some of the largest trees were not encountered during random sampling but we measured the girth of the largest of each species independently of Point Quarter analyses to show the upper limit of size variation (Table 1). The largest trees in the stand were Acer saccharum and A. nigrum and the next largest Fagus grandifolia and Juglans nigra. Maximum sizes of Acer rubrum, Carya cordiformis and Prunus serotina were somewhat smaller, and all other tree species were lower yet, with the exception of the small understorey trees of Ostrya virginiana and Carpinus caroliniana. Ostrya is typically sapling size, and in Ontario a specimen as large as that encountered at UWO is seen only rarely.

\section{Composition of tree layer}

Trees present are listed in order of decreasing importance in Table 2, along with full data on composition of the tree layer as well as calculations based on these. Eighteen tree species, all represented by tree-sized members, was a relatively high number for a mesic deciduous forest in the region. All were deciduous and only one, Prunus avium (sweet cherry), which is freely spread from or- 
Table 1. Basal areas $\left(\mathrm{cm}^{2}\right)$ of the largest specimens of each tree species found in a mesic deciduous forest, University of Western Ontario campus, London, Ontario, Canada. * Introduced species.

\begin{tabular}{lclc}
\hline \multicolumn{1}{c}{ Species } & Basal area $\left(\mathrm{cm}^{2}\right)$ & \multicolumn{1}{c}{ Species } & Basal area $\left(\mathrm{cm}^{2}\right)$ \\
\hline Acer saccharum & 5806 & Fraxinus americana & 1806 \\
Acer nigrum & 5677 & Ulmus americana & 1613 \\
Fagus grandifolia & 4516 & Quercus rubra & 2387 \\
Juglans nigra & 4355 & Ulmus rubra & 1045 \\
Acer rubrum & 4000 & Tilia americana & 903 \\
Carya cordiformis & 3355 & *Prunus avium & 516 \\
Prunus serotina & 3161 & Celtis occidentalis & 419 \\
Ostrya virginiana & 2194 & Carpinus caroliniana & 290 \\
Juglans cinerea & 1935 & Quercus macrocarpa & 548 \\
\hline
\end{tabular}

Table 2. Composition of a remnant mesic stand of deciduous forest, University of Western Ontario, London, Ontario. Summary of frequency, density, dominance and importance calculations for the tree layer. * Introduced species.

\begin{tabular}{|c|c|c|c|c|c|c|c|c|c|c|c|}
\hline \multirow[t]{2}{*}{ Species } & \multirow[b]{2}{*}{$\begin{array}{l}\text { No. } \\
\text { pts. }\end{array}$} & \multirow[b]{2}{*}{$\begin{array}{l}\text { No. } \\
\text { trees }\end{array}$} & \multicolumn{3}{|c|}{ Size classes } & \multirow[b]{2}{*}{$\begin{array}{c}\text { Total } \\
\text { domina } \\
\text { nce } \\
\left(\mathrm{cm}^{2}\right)\end{array}$} & \multirow[b]{2}{*}{$\begin{array}{l}\text { Freq. } \\
\text { trees }\end{array}$} & \multirow[b]{2}{*}{$\begin{array}{l}\text { Rel. } \\
\text { freq. }\end{array}$} & \multirow[b]{2}{*}{$\begin{array}{c}\text { Rel. } \\
\text { densi } \\
\text { ty }\end{array}$} & \multirow[b]{2}{*}{$\begin{array}{l}\text { Rel. } \\
\text { dom. }\end{array}$} & \multirow[b]{2}{*}{$\begin{array}{l}\text { DFD } \\
\text { Importance } \\
\text { value }\end{array}$} \\
\hline & & & $\begin{array}{l}-516 \\
\mathrm{~cm}^{2}\end{array}$ & $\begin{array}{l}-2064 \\
\mathrm{~cm}^{2}\end{array}$ & $\begin{array}{l}-8256 \\
\mathrm{~cm}^{2}\end{array}$ & & & & & & \\
\hline Acer saccharum & 17 & 30 & 21 & 6 & 3 & 3053 & 85 & 29 & 38 & 37 & 104 \\
\hline Acer nigrum & 10 & 15 & 13 & 2 & - & 674 & 50 & 17 & 19 & 8 & 44 \\
\hline Ostrya virginiana & 9 & 11 & 9 & 2 & - & 492 & 45 & 16 & 14 & 6 & 35 \\
\hline Fagus grandifolia & 3 & 3 & - & 1 & 2 & 1308 & 15 & 5 & 4 & 16 & 25 \\
\hline Prunus serotina & 5 & 6 & 5 & - & 1 & 615 & 25 & 9 & 8 & 8 & 24 \\
\hline Carya cordiformis & 2 & 2 & - & 1 & 1 & 740 & 10 & 3 & 3 & 9 & 15 \\
\hline Tilia americana & 4 & 4 & 3 & 1 & - & 239 & 20 & 7 & 5 & 3 & 15 \\
\hline Juglans nigra & 2 & 2 & - & 1 & 1 & 625 & 10 & 3 & 3 & 8 & 14 \\
\hline Ulmus rubra & 3 & 4 & 3 & 1 & - & 209 & 15 & 5 & 5 & 3 & 13 \\
\hline Fraxinus americana & 1 & 1 & - & 1 & - & 143 & 5 & 2 & 1 & 2 & 5 \\
\hline Quercus rubra & 1 & 1 & 1 & - & - & 55 & 5 & 2 & 1 & 1 & 4 \\
\hline $\begin{array}{l}\text { Carpinus } \\
\text { caroliniana }\end{array}$ & 1 & 1 & 1 & - & - & 46 & 5 & 2 & 1 & 1 & 4 \\
\hline Ulmus americana & - & - & - & - & - & - & - & - & - & - & 1 \\
\hline Acer rubrum & - & - & - & - & - & - & - & - & - & - & 1 \\
\hline Juglans cinerea & - & - & - & - & - & - & - & - & - & - & 1 \\
\hline $\begin{array}{l}\text { Quercus } \\
\text { macrocarpa }\end{array}$ & - & - & - & - & - & - & - & - & - & - & 1 \\
\hline Celtis occidentalis & - & - & - & - & - & - & - & - & - & - & 1 \\
\hline *Prunus avium & - & - & - & - & - & - & - & - & - & - & 1 \\
\hline TOTALS & 20 & 80 & $70 \%$ & $20 \%$ & $10 \%$ & 8199. & 290 & 100 & 100 & 100 & 300 \\
\hline
\end{tabular}

chards by birds, was not native. Acer saccharum with an importance value of 104 was the only significant dominant, thus forming more than a third of the stand. Acer nigrum was the first subdominant with an importance of 44 while Ostrya virginiana, confined largely to the sec- ond canopy, was a close second with importance of 35 . Two species with lesser importance of approximately 25, Fagus grandifolia and Prunus serotina respectively, were represented by large members, but these were quite scattered and restricted in occurrence. Four species including 
Table 3. Composition of a mesic deciduous forest fragment, University of Western Ontario, London, Ontario. Summary of frequency and density for the sapling layer.

\begin{tabular}{lcccccc}
\hline Species & $\begin{array}{l}\text { No. } \\
\text { points }\end{array}$ & No. saplings & $\begin{array}{l}\text { Frequency } \\
\text { saplings }\end{array}$ & $\begin{array}{l}\text { Rel. } \\
\text { freq. }\end{array}$ & $\begin{array}{l}\text { Rel. } \\
\text { density }\end{array}$ & DF value \\
\hline Acer saccharum & 15 & 34 & 75 & 37 & 43 & 80 \\
Acer nigrum & 12 & 28 & 60 & 29 & 35 & 64 \\
$\begin{array}{l}\text { Carpinus } \\
\text { caroliniana }\end{array}$ & 4 & 7 & 20 & 10 & 9 & 19 \\
Fagus grandifolia & 3 & 4 & 15 & 8 & 5 & 12 \\
Tilia americana & 2 & 2 & 10 & 5 & 3 & 8 \\
Carya cordiformis & 2 & 2 & 10 & 5 & 3 & 8 \\
Ostrya virginiana & 1 & 1 & 5 & 2 & 1 & 3 \\
Prunus serotina & 1 & 1 & 5 & 2 & 1 & 3 \\
Ulmus americana & 1 & 1 & 5 & 2 & 1 & 3 \\
Totals & 20 & 80 & 205 & 100 & 100 & 200 \\
\hline
\end{tabular}

Carya cordiformis, Tilia americana, Juglans nigra and Ulmus rubra, each had importance values of approximately 15 . These contributed $5 \%$ of tree cover and were found generally as large, very scattered trees, although Tilia specimens were smaller and more numerous than others. Three species each with importance values of approximately 5 were quite minor; Fraxinus americana and Quercus rubra were each represented by a small number of trees and Carpinus caroliniana was conspicuous where it occurred but was mostly restricted to the north sector of the forest. Six other tree species present in the stand were assigned an importance value of one. Ulmus americana, Acer rubrum, Juglans cinerea, Quercus macrocarpa and Celtis occidentalis were all represented by large scattered trees, and Prunus avium was present as only a single smaller tree.

Age

A large fallen beech $\left(2193 \mathrm{~cm}^{2} \mathrm{BABH}\right)$ analyzed in Springwater Forest was 150 yr old. The first 75 annual growth rings accounted for $15 \mathrm{~cm}$ of radius and the next $75 \mathrm{yr} 10 \mathrm{~cm}$. Ring widths would continue to decline with age and extrapolation would suggest that, if the tree had continued to grow, the next $75 \mathrm{yr}$ might have contributed $5 \mathrm{~cm}$ radial increase. If this rate were sustained, the largest beech in the UWO forest with BABH of $4516 \mathrm{~cm}^{2}$ and radius of $37.9 \mathrm{~cm}$ might have been as old as $400 \mathrm{yr}$, but surely at least 360 . Springwater and UWO sites are similar in many ways, so sugar maple and beech probably perform similarly in the two. If so, the largest sugar maple, $5806 \mathrm{~cm}^{2} \mathrm{BABH}$, radius of $42.9 \mathrm{~cm}$, would have attained an age of well over $435 \mathrm{yr}$. One enormous standing dead snap-off maple with diameter of $102 \mathrm{~cm}$ and BABH 8172 $\mathrm{cm}^{2}$ was too deteriorated to age, but must have been more than $500 \mathrm{yr}$ old when damaged. In any case, such large specimens, with estimates of age based on tree ring analyses, supported the idea the forest is old. In terms of size classes, $70 \%$ of trees in the UWO forest fell into the lowest size class, with $20 \%$ in the next and $10 \%$ in the third class.

\section{Reproduction and future stand development}

Quantitative data on sapling representation is presented in Table 3. Of the 18 species of trees present only half, or 9, were represented by saplings in the lowest canopy, and most of those occurred in low numbers. Acer saccharum was a strongly-represented dominant in the reproduction layer. The relative density of saplings was $43 \%$, while that of trees was similar, $38 \%$. The second most important species contributing saplings was Acer nigrum and the relative density value of its saplings (35\%) was much more than that of its trees. Fagus grandifolia had a fair sapling representation but Tilia americana and Carya cordiformis, and particularly Prunus serotina and Ostrya virginiana had considerably lower numbers of saplings per ha than trees. Besides the two maple species referred to above, only Carpinus caroliniana and perhaps Ulmus americana registered more saplings than trees on a relative basis, but the differences were very modest.

\section{Understorey composition}

In the spring of 1999, maximum cover in the understorey was achieved between mid-April and mid-May and attained a value of $52 \%$, with Erythronium albidum con- 
Table 4. Understorey composition of a small mesic deciduous forest fragment, University of Western Ontario campus, London, Ontario. Presence, frequency and estimated percent cover. ${ }^{*}$ Introduced species.

\begin{tabular}{|c|c|c|c|c|c|}
\hline Species & Frequency & $\begin{array}{c}\% \\
\text { Cover }\end{array}$ & Species & Frequency & $\begin{array}{l}\% \\
\text { Cover }\end{array}$ \\
\hline Erythronium americanum & 75 & 20.5 & Trillium grandiflorum & 1 & 0.0 \\
\hline Erythronium albidum & 65 & 21.5 & Cornus alternifolia & 1 & 0.0 \\
\hline Smilacina racemosa & 50 & 43 & Allium tricoccum & 1 & 0.0 \\
\hline Primus virginiana & 40 & 16.2 & Carex jamesii & 1 & 0.0 \\
\hline *Alliaria officinalis & 40 & 3.2 & Carex blanda & 1 & 0.0 \\
\hline Arisaema atrorubens & 40 & 2.0 & Carex hirtifolia & 1 & 0.0 \\
\hline Podophyllum peltatum & 20 & 8.5 & Trillium erectum & 1 & 0.0 \\
\hline Hydrophyllum virginianum & 20 & 4.0 & Solidago flexicaulis & 1 & 0.0 \\
\hline Euonymus obovatus & 20 & 1.5 & Viburnum lentago & 1 & 0.0 \\
\hline Dentaria laciniata & 20 & 1.4 & Ribes cynosbati & 1 & 0.0 \\
\hline Circaea quadrisulcata & 10 & 6.5 & Vitis riparia & 1 & 0.0 \\
\hline Acer saccharum & 10 & 3.0 & Tovara virginiana & 1 & 0.0 \\
\hline Geum canadense & 0.5 & 0.2 & Aster lateriflorus & 1 & 0.0 \\
\hline Geranium maculatum & 1 & 0.0 & Euonymus atropurpureus & 1 & 0.0 \\
\hline Viburnum trilobum & 1 & 0.0 & Solidago caesia & 1 & 0.0 \\
\hline Carex convoluta & 1 & 0.0 & Rubus occidentalis & 1 & 0.0 \\
\hline *Rhamnus cathartica & 1 & 0.0 & Carex brunnescens & 1 & 0.0 \\
\hline Actaea pachypoda & 1 & 0.0 & Rhus radicans & 1 & 0.0 \\
\hline *Epipactis helleborine & 1 & 0.0 & Dentaria laciniata & 1 & 0.0 \\
\hline
\end{tabular}

tributing cover of $21.5 \%$, E. americanum $20.5 \%$ and Dentaria laciniata $1.4 \%$. Thus, these three ephemerals contributed ground cover of $43.4 \%$ in the spring, a contribution that was almost $84 \%$ of total all-season understory cover. This reflected the relative sparcity of understorey cover in summer.

Composition of the summer understorey, as sampled in early July, 1991, is shown in Table 4. Thirty-eight vascular plant species were observed, one of which was Acer saccharum, occurring as seedlings, but its cover of only $3 \%$ indicates that it was not a significant contributor to ground vegetation, at least that year. Total ground cover in July was $31.5 \%$, with twelve herbs and shrubs contributing, seven quite significantly. Of all understorey species Erythronium albidum and E. americanum produced in spring the highest cover values, $21.5 \%$ and $20.5 \%$, respectively, while in summer Prunus virginiana had next highest (16.2\%), followed by Podophyllum peltatum (8.5\%), Circaea quadrisulcata (6.5\%), and Smilacina racemosa and Hydrophyllum virginianum which had $4.3 \%$ and
4.0\%, respectively. Arisaema atrorubens, Alliaria officinalis, Euonymus obovatus, Acer saccharum Dentaria laciniata and Geum canadense, all contributed cover of $3.2 \%$ or less. The summed cover of these species totalled $43 \%$ but, due to overlapping, the total understorey cover was estimated at approximately $35 \%$. Of the 29 remaining species, the following were each observed on several occasions during reconnaisance and thus contributed at least minimally to total cover: Viburnum trilobum, Carex convoluta, Rhamnus cathartica, Trillium grandiflorum, $T$. erectum, Cornus alternifolia, Carex blanda, Solidago flexicaulis, Ribes cynosbati and Carex brunnescens.

\section{$D C A$}

Figure 1 shows the first two axes of DCA based on stand data. The first axis accounted for $31.4 \%$ of variance and the second an additional $10.1 \%$ of the total trace. A strong spread of stands was seen along the first axis and more modest separation along the second. Of decided significance is the observation that the UWO forest (Stand 
197) was not an outlier, distinct from others in the complex, but was definitely integrated among larger old growth stands in the ordination. The UWO forest on the far left was quite near stands 50 (Rondeau), 79 (Blenheim) and 203 (Jaffa Ridge in Springwater Forest). In fact it was more similar to other stands in the ordination than certain stands within the Springwater Forest complex (41, 198, 200, 201, 203 and 206) were to each other.

Stand groupings produced by DCA (Fig. 1) indicated that the basis for separation along the first two axes may have been related to the way importance was divided, mainly among three ecologically significant tree species. Acer saccharum (Fig. 2a) had highest importance in five stands in the upper left. On the other hand, stands in the lower right had decidedly low importance values for $A$. saccharum and high importance of Fagus grandifolia (Fig. 2b). Values for Acer nigrum (not shown), which is usually a less important tree in the deciduous forests of extreme Southern Ontario, were lower than those for sugar maple or beech, and stands including the highest representations for this species were pulled together in the upper left of the ordination. The positioning of the UWO forest toward the left of the first axis could thus be partly related to the significant contribution of black maple. Two other tree species of much lesser importance supported this continuity. Pinus strobus (Fig. 2c) reached its highest levels in what may have been slightly drier-than-mesic stands to the right that were dominated by Fagus grandifolia, while Ulmus americana (Fig. 2d) had higher importance in stands to the left that mav have been somewhat moister-than-mesic stands. Other tree species contributed less to the separation.

Figure 3 is the ordination of tree species, providing an indication of where major dominants and minor species attain ecological optimum. Acer saccharum and Fagus grandifolia were situated centrally and in relatively close proximity in ordinational space. The positions of minor species provided an indication of the basis for separation along the first axis. On the right, relatively dry species including the oaks, Quercus rubra, Q. alba and Pinus strobus, attained optima, whereas Ulmus americana, Carya cordiformis and Fraxinus nigra, all moister species, attained highest importance on the far left. Thus, the first axis may separate forests slightly more drier than mesic on the right from those slightly moister on the left. The second axis may represent a fertility gradient, from stands with relatively high nutrient availability at the top to those somewhat lower below, although this trend is not so clearly evident as the moisture trend on the first axis.

The ordination may also be related to additional environmental features. Stands to the right of the first axis tend to be on sandy loams and those toward the left on loams and silty loams, although this separation is not perfect. Fagus grandifolia seems to reach higher levels of importance on sandy loams, while Acer species predominate on loams and silty loams. Such a tendency has been noted previously in the forested region of extreme southern Ontario (Mavcock 1963).

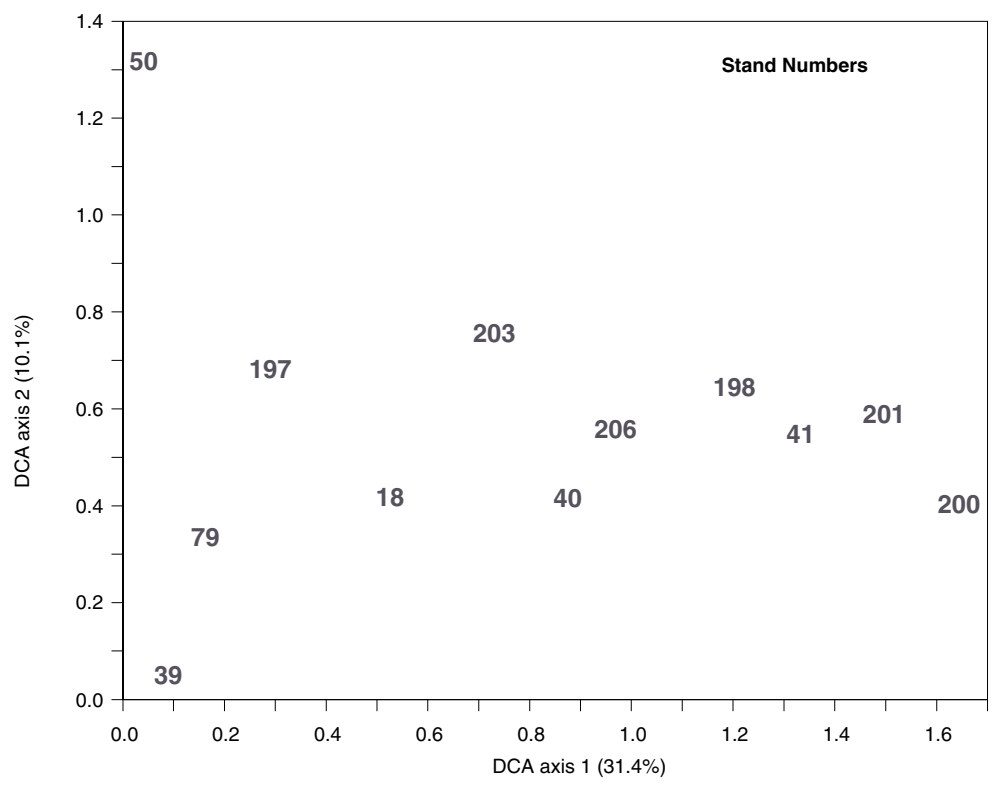

Figure 1. Detrended Correspondence Analysis of old-growth deciduous forest stands in extreme Southern Ontario based on importance values (sum of relative frequency, relative density and relative density) of all tree species. 

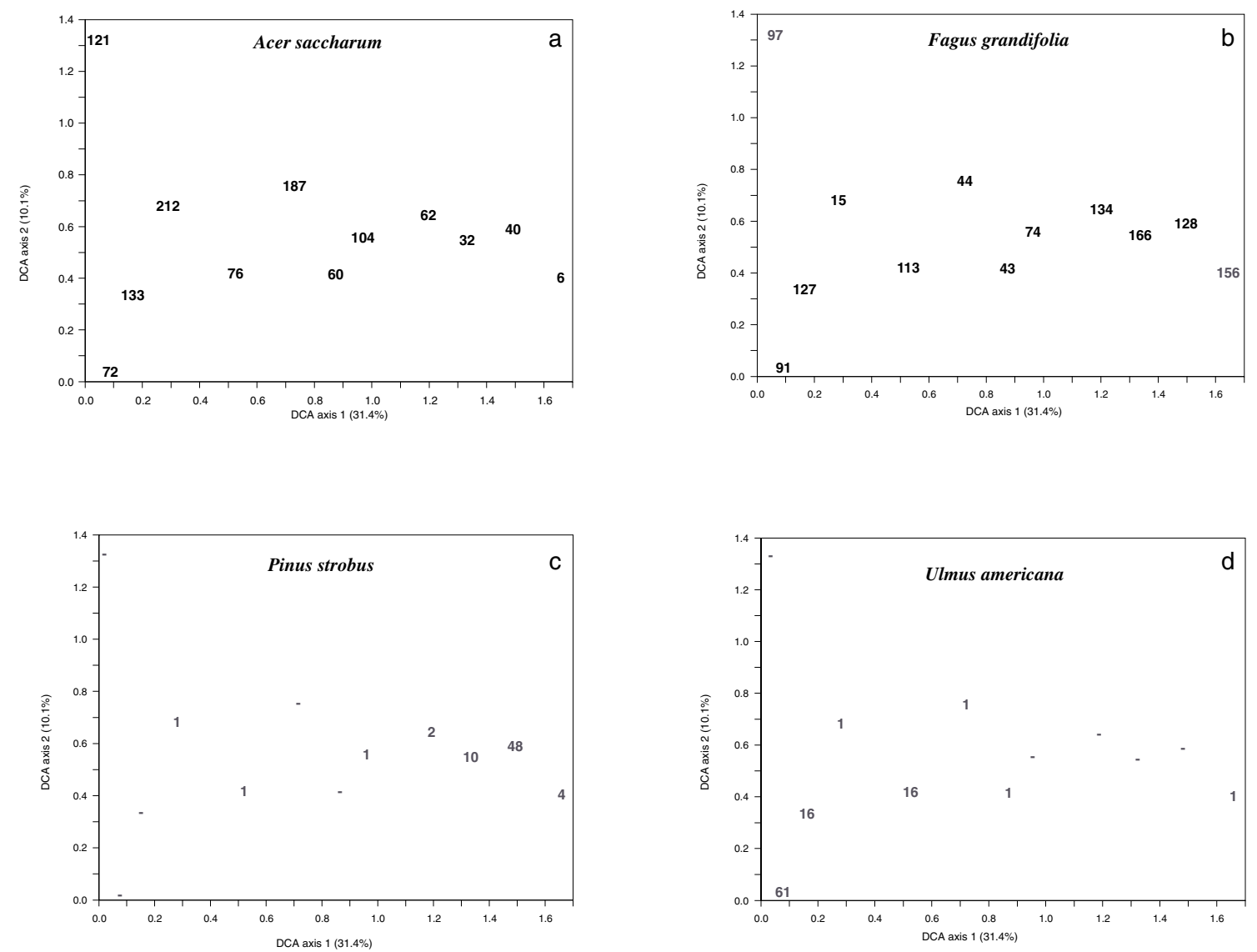

Figure 2. Detrended Correspondence Analysis ordination of old-growth deciduous forest stands in extreme Southern Ontario with importance values of trees plotted for each stand. a) Acer saccharum, a dominant tree species, b) Fagus grandifolia, a dominant tree, c) Pinus strobus, a minor tree species, d) Ulmus americana, a minor tree species.

We presented a number of significant compositional and structural features of the UWO site in Table 5, along with those of eleven mesic old-growth systems in the Deciduous Forest region of extreme Southern Ontario. Some of these forests comprise extensive areas, whereas others may be just marginally larger than the UWO forest but part of a much more extensive and variable forest complex. Comparatively, the total flora of the UWO forest was not particularly rich, containing only 55 species, the lowest number of the 12 southern Ontario forests compared. The next richest example, with 65 species, is Springwater Forest in Elgin County and other stands have totals of $71-128$ species.

\section{Discussion}

Composition of the small UWO forest was remarkable for southern Ontario. The large number of tree species present, 18 total with 12 having quantitative representation in the data, makes it an unusually rich example of mesic deciduous forest. Other outstanding and unusual compositional features, at least for the region, were the relatively high importance of Acer nigrum in a stand strongly dominated by Acer saccharum, and the upland occurrence of Acer rubrum.

The 11 mesic old-growth stands in southern Ontario used for comparison exhibited a wide range of percentages of trees in each size class, and representation in the lowest size class at UWO was higher than in any stands from larger forests, the nearest value being $57 \%$. However, UWO had less representation in the second class and was typical of old-growth stands in terms of the proportion of trees $(10 \%)$ in the next larger or third size class. Overall, the size class distribution at UWO was similar to that in old-growth sites such as at Lakeview, Backus and Sparta, suggesting that it is at a similar stage of successional development.

The high percentages of sapling and trees of sugar maple and black maple observed in the smallest size class also supported the notion that the UWO forest is self- 
Table 5. Compositional and structural features of UWO remnant forest and selected mesic old-growth deciduous forests in Southern Ontario. Stands ordered on tree species richness.

\begin{tabular}{|c|c|c|c|c|c|c|c|c|c|c|c|c|}
\hline \multicolumn{13}{|c|}{ Stands } \\
\hline Feature & $\begin{array}{c}79 \\
\text { Blenheim }\end{array}$ & $\begin{array}{c}201 \\
\text { Spring } \\
\text { S.W. }\end{array}$ & $\begin{array}{c}198 \\
\text { Spring } \\
\text { III }\end{array}$ & $\begin{array}{c}39 \\
\text { Lakeview }\end{array}$ & $\begin{array}{c}203 \\
\text { Jaffa } \\
\text { Ridge }\end{array}$ & $\begin{array}{l}200 \\
\text { Spring } \\
\text { Pond }\end{array}$ & $\begin{array}{l}206 \\
\text { Jaffa } \\
\text { Cent. }\end{array}$ & $\begin{array}{c}41 \\
\text { White's } \\
\text { Woods }\end{array}$ & $\begin{array}{c}50 \\
\text { Rondeau }\end{array}$ & $\begin{array}{l}197 \\
\text { UWO }\end{array}$ & $\begin{array}{c}18 \\
\text { Backus } \\
\text { Woods }\end{array}$ & $\begin{array}{c}40 \\
\text { Sparta }\end{array}$ \\
\hline No. tree species & 9 & 12 & 13 & 13 & 14 & 14 & 14 & 14 & 15 & 18 & 18 & 20 \\
\hline No. shrub species & 9 & 12 & 13 & 10 & 10 & 13 & 12 & 12 & 9 & 8 & 12 & 13 \\
\hline No. liana species & 2 & -- & 6 & 1 & 3 & 3 & 5 & 3 & 3 & 2 & 6 & 5 \\
\hline Total vascular species & 81 & 71 & 65 & 95 & 76 & 77 & 87 & 94 & 85 & 54 & 128 & 111 \\
\hline Trees/ha & 205 & 343 & 272 & 657 & 519 & 437 & 377 & 304 & 302 & 773 & 348 & 479 \\
\hline B.A./ha $\left(\mathrm{cm}^{2} \times 1000\right)$ & 382 & 520 & 414 & 393 & 545 & 558 & 437 & 473 & 373 & 511 & 865 & 355 \\
\hline III, $2064-8255 \mathrm{~cm}^{2}$ & 40 & 32 & 29 & 1 & 14 & 24 & 16 & 26 & 15 & 10 & 7 & 8 \\
\hline IV, $8256 \mathrm{~cm}^{2}$ & -- & -- & -- & -- & -- & -- & -- & 1 & - & -- & -- & -- \\
\hline \multicolumn{13}{|l|}{ Importance values } \\
\hline Acer saccharum & 134 & 41 & 63 & 72 & 189 & 6 & 105 & 32 & 121 & 104 & 77 & 60 \\
\hline Fagus grandifolia & 128 & 129 & 135 & 92 & 44 & 157 & 74 & 167 & 97 & 25 & 114 & 43 \\
\hline Acer nigrum & +- & -- & -- & -- & 3 & -- & -- & 2 & 6 & 44 & - & - \\
\hline
\end{tabular}

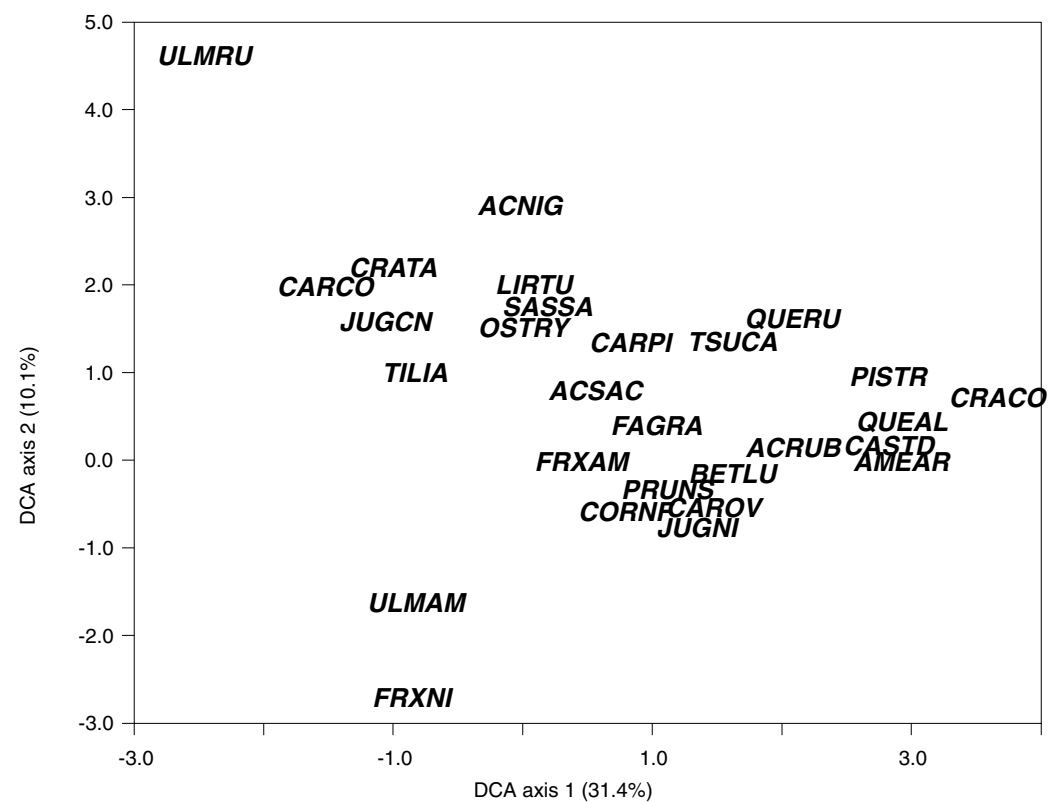

Figure 3. Detrended Correspondence Analysis of all tree species included in old-growth deciduous forest stands in extreme Southern Ontario based on importance values. Tree species codes: ACNIG - Acer nigrum; ACRUB - Acer rubrum; ACSAC - Acer saccharum; AMEAR - Amelanchier arborea; BETLU - Betula lutea; CARCO - Carya cordiformis; CAROV - Carya ovata; CARPI - Carpinus caroliniana; CORNF - Cornus florida; CRACO - Crataegus corusca; CRATA - Crataegus spp.; FAGRA - Fagus grandifolia; FRXAM - Fraxinus americana; FRXNI - Fraxinus nigra; JUGCN - Juglans cinerea; JUGNI Juglans nigra; LIRTU - Liriodendron tulipifera; OSTRY - Ostrya virginiana; PISTR - Pinus strobus; PRUNS - Prunus serotina; QUEAL - Quercus alba, QUERU - Quercus rubra; SASSA - Sassafras albidum; TILIA - Tilia_americana; TSUCA Tsuga canadensis; ULMUS - Ulmus americana; ULMRU - Ulmus rubra. 
maintaining. That nearly $75 \%$ of saplings were maple indicates that as older maples are lost by wind or or other natural factors these species will be maintained in the upper canopies or even increased. The sapling representation of Fagus grandifolia indicates that this species may be perpetuated as well. Except for Carpinus carolini$a n a$, other tree species showed little if any reproduction, suggesting limited possibilities for expanding into the next generation of the forest, at least barring major catastrophies to the upper canopies. This pointed to continued dominance of maples, perhaps even stronger than at present. Thus, the forest is a stable climax with composition that will probably be maintained for a considerable time.

Mesic forests strongly dominated by maple, with relatively low levels of beech, typically show less diversity than beech-dominated forests, and the floristic richness of UWO is more modest than the other stands with which it is compared here. Understorey herbs is the life-form class that usually contributes most significantly to the total vascular flora of many old-growth stands, but representation of understorey herbs was relatively low at UWO, reducing the total vascular flora. Low understorey diversity may be related to the strong dominance exerted by Acer saccharum, the most shade tolerant and aggressive tree of mesic sites (Curtis 1959), as well as by A. nigrum. These two tree species, accounting for almost half of stand importance of trees and in addition almost three quarters of the sapling layer, produce an exceedingly dense shade that may limit establishment and survival of other plants. They probably also influence strongly litter charactacteristics and the nutrient status of the soil. The low total number of vascular species at UWO may be partly due to limited stand size, but perhaps also to the close proximity of anthropogenically altered environments (Honnay et al. 1999). However, the herbaceous layer in deciduous forests of Ontario has been shown by Burke and Nol (1998) to be more species-rich nearer forest edges than in forest interiors. These authors showed that interior levels of diversity were achieved within $5 \mathrm{~m}$ from the edge, and on this basis, it seems unlikely that edge effects would have accounted for low diversity in the UWO forest fragment. Nevertheless, despite sustaining only a moderate-sized flora, UWO supported three understorey species wich are considered provincially rare.

\section{UWO in relation to stands from large old-growth forests}

With respect to stand ordination it should be emphasized that the stands for comparison with UWO were chosen because of their floristic and environmental similarities. All were old deciduous hardwood stands on flat to gently-rolling mesic sites within the same region, thus trends indicated by ordination would be based on relatively subtle differences. Nevertheless, the trend on the first axis was the same as often occurs in vegetational analysis, that is, it was based largely on site moisture, and separated somewhat drier from slightly more mesic stands. Most importantly, the ordination demonstrated that the UWO forest shows an appreciable compositional and environmental similarity to old-growth systems in the region.

Structural features of the UWO system were characteristic of old-growth. First, a number of trees in the upper canopy were very large, exceeding $2000 \mathrm{~cm}^{2} \mathrm{BABH}$, with the oldest and largest of these probably similar to trees encountered in southern Ontario at the time of European settlement (McNab 1835). Trees were uneven-aged with significant members in several size classes, and the stand was compositionally stable. A number of dead and standing trees occurred throughout the forest, primarily large old Ostrya virginiana, but also Acer saccharum and Fagus grandifolia. A multiple-layered canopy, considered to characterize old-growth, was also present. Furthermore, the ground was littered with dead fallen snapoffs and branch debris. The soil profile was intact, as was the understorey. In addition, there was no evidence of major disturbances such as logging, with the exception of recent safety-topping of a few large marginally located trees. Also, in spite of some human influence, there were few introduced alien species. The only old-growth criteria listed by Leverett that did not characterize the UWO stand were canopy gaps and pit-mound topography connected to windthrow. Pit-mounds and possibly gaps may have been lacking because old trees died standing and were snapped off, rather than tipped and uprooted. However, few bona fide old-growth forests display a full complement of "old-growth features" (Habeck 1988, Leverett 1996). UWO has essentially as many features as most of these forests, in spite of being small and surrounded by human influence.

\section{Preservation of the small UWO forest fragment}

The UWO forest site is obviously worthy of protection for its old-growth characteristics alone, because examples are becoming so rare. However, the unusual and significant high representation of Acer nigrum, large old Ostrya virginiana specimens and provincially rare understorey species, constitute additional features that warrant preservation. To ensure continued survival of this remarkable old-growth remnant, complete protection is probably necessary. Easy footpath entrances have already been obstructed with fallen branches and explanations have been posted regarding the scientific importance of the forest, 
both measures which have discouraged intrusion and promoted re-establishment of native plants in some areas. A hands-off policy in relation to dead trees and branches has been adopted: safety topping will no longer take place and neither will pruning of trees be permitted around the periphery. It is important to ensure that aggressive alien species at some points along the edge do not penetrate further, and in time it may become necessary to permit forest expansion into a buffer zone and perhaps even also to provide protective fencing.

While many vegetational criteria of old-growth were exhibited at UWO, all elements of an intact old-growth ecosystem cannot necessarily be maintained in such a small area. Much more extensive reserves than those at UWO would be required to sustain extremely species-rich vegetation (such as tropical forests) and to satisfy habitat requirements of fauna such as songbirds and larger animals. It is surely true that large contiguous forests are preferable for conservation purposes (Honnay et al. 1999), but at the same time the importance of remnants should not be underestimated. It is evident that a stand of maple-beech forest much smaller than the 8 ha defined by Leopold (1988) may certainly exhibit a large number of structural, reproductive and historical features of oldgrowth and serve as a valuable ecological benchmark.

Acknowledgements: We wish to thank Dr. Peter W. Ball, Department of Botany, Erindale College, Mississauga who identified or verified Carex specimens and Dr. James Phipps, Department of Plant Science who identified Crataegus, and Dr. Terence Carleton, Department of Botany, University of Toronto who produced the DCA ordinations.

\section{References}

Ball, P.W., and D.J. White. 1982. Cyperaceae. In: G.W. Argus and D.J. White (eds.), Atlas of the Rare Vascular Plants of Ontario. Botany Division; National Museum of Science, Ottawa. pp.

Brisson, J., Y. Bergeron and A. Bouchard. 1992. The history and tree stratum of an old-growth forest of Haut-Saint-Laurent Region, Quebec. Nat. Areas J. 12:3-9.

Burke, D.M., and E. Nol. 1998. Edge and fragment size effects on the vegetation of deciduous forests in Ontario, Canada. Nat. Areas $J$. 18:45-53.

Curtis, J.T. 1959. The Vegetation of Wisconsin. University of Wisconsin Press. Madison, Wisconsin.

Dreimanis, A., C.G. Winder, and R.A.Altonen. 1998. London, Ontario: Geology. Geomorphology. Geodata. In: P.F. Karrow and O.L. White (eds), Urban Geology of Canadian Cities. Geological Association of Canada Special Paper 42. pp. 237-260.

Fernald, M.L. 1950. Gray's Manual of Botany. D. Van Nostrand Company, New York.
Habeck, J.R. 1988. Old-growth forests in the northern Rocky Mountains. Nat. Areas J. 8:202-211.

Hill, M.O. and H.G. Gauch. 1980. Detrended Correspondence Analysis: an improved ordination technique. Vegetatio 42:4258.

Honnay, O., P. Endels, H. Vereecken, and M. Hermy. 1999. The role of patch area and habitat diversity in explaining native plant species richness in disturbed suburban forest patches in Northern Belgium. Biodiversity Research 5:129-141.

Hunter, M.L., and A.S. White. 1997. Ecological thresholds and the definition of old-growth forest stands. Nat. Areas J. 17:292-296.

Juday, G.P. 1988. Old-growth forests and natural areas: an introduction. Nat. Areas J. 8:3-6.

Keddy, C. 1984. Celastraceae. In: G.W. Argus and D.J. White (eds), Atlas of the Rare Vascular Plants of Ontario. Botany Division, National Museum of Science, Ottawa. pp.

Leopold, D.J., C. Reschke and D.S. Smith. 1988. Old-growth forests of Adirondack Park, New York. Nat. Areas J. 8:166-189.

Leverett, R. 1991. Identifying old-growth forest in the East. Wild Earth 1: 30-34.

Leverett, R. 1996. Definitions and history. In: M.B. Davis (ed), Eastern Old-growth Forests. Island Press, pp. 3-17.

Martin, W.H. 1992. Characteristics of old-growth mixed mesophytic forests. Nat. Areas J. 12: 127-135.

Maycock, P.F. 1963. The phytosociology of the deciduous forests of extreme southern Ontario. Can. J. Bot. 41:379-438.

$\mathrm{McNab}, \mathrm{J} .1835$. On the local distribution of different species of trees in the native forests of America. Quarterly Journal of Agriculture 5:594-605.

Nowacki, G.J., and P.A. Trianonsky. 1993. Literature on old-growth forests of eastern North America. Nat. Areas J. 13: 87-107.

Oliver, C.D., and B.C. Larson. 1990. Forest Stand Dynamics. McGraw-Hill, Inc., New York.

Parker, G.R. 1989. Old-growth forests of the central hardwood regions. Nat. Areas J. 9:5-11.

Peterken, G.F. 1992. Conservation of old growth: a European perspective. Nat. Areas J. 12:10-19.

Pfister, R.D. 1987. Old-growth definition, classification and application. USDA Forest Service, Final Contract Report RFQ 185$131 \mathrm{Q}$.

Runkle, J.R. 1996. Central mesophytic forests. In: M. B. David (ed.), Eastern Old-growth Forests. Island Press, pp. 161-177.

Spies, R.A., and J.F. Franklin. 1988. Old growth and forest dynamics in the Douglas-Fir Region of Western Oregon and Washington. Nat. Areas J. 8:190-201.

Tyrrell, L.E., G.L. Nowacki, T.R. Crow, D.S. Buckley, E.A. Navertz, J.N. Niese, J.L. Rollinger, and J.C. Zasada. 1998. Information about old growth for selected forest type groups in the eastern United States. USDA Forest Service Tech. Rep. NC-197.

Wells, R.W., K.P. Lertzman and S.C. Saunders. 1998. Old-growth definitions for the forests of British Columbia, Canada. Nat. Areas J. 18:279-292. 